\title{
8 Export Expansion, Capital Accumulation and Distribution in Turkish Manufacturing, 1980-9
}

\author{
Fatma Taskin and A. Erinc Yeldan
}

In the early 1980s, Turkey started to pursue an export-oriented growth strategy centred on manufactured exports. Stimulated mainly by a vigorous export promotion strategy which consisted of high export subsidies, competitive devaluations of the Turkish lira, and repression of domestic demand, Turkey increased the total value of its merchandise exports fourfold by the first half of the 1980s. While the economic and political effects of this episode are in general well-documented, (for example, Celasun and Rodrik, 1989; Senses and Yamada, 1990; Onis and Riedel, 1993), its income distribution consequences remain unexplored. Indeed, throughout the decade, the observed rapid surge in manufacturing exports appear to have been accompanied by faltering rates of capital accumulation and a deterioration in the purchasing power of the working classes. Although there are references to the problem in the Turkish literature (see, for example, Celasun, 1989; Yeldan, 1993; Boratav, 1992), a formal analysis of the linkages between export expansion and income redistribution is yet to be undertaken.

In this chapter we analyse the historical links between exports, growth, employment and (functional) distribution of income within the Turkish manufacturing sector which was the main target of export promotion policies exclusively targeted. The paper consists of three sections: the first section provides an overview of the manufacturing export performance, with special emphasis on the economic policies that shaped the formation of price and cost structure within the sector; Section 2 provides a more detailed sectional analysis of the export drive, while Section 3 analyses the trend in export expansion, accumulation and distribution. 


\section{EXPORT PERFORMANCE OF THE MANUFACTURING SECTOR}

The introduction of the stabilization program in 1980s induced a sharp increase in exports. Between 1980 and 1990, the total merchandise exports quadrupled and the export value which was 2910.0 million US dollars in 1980 reached 12959.3 million US dollars by 1990. During the period, the average annual growth rate for exports reached 17 per cent; the ratio of exports to GNP (in current prices) was only 5 per cent in 1980 , reached 15.6 per cent in 1985 and was at 16 per cent by the second half of the decade (see Table 8.2). This export boom has been the most important factor in the recovery of Turkish economy since 1980 . It has also had a major role in increasing the creditworthiness of Turkey.

In addition to the increase in absolute levels of exports, there were structural changes. The period witnessed a transformation both in the composition and geographical destination of Turkish exports. At the beginning of the period 57.4 per cent of the total exports was agricultural goods and only 35.9 per cent was industrial goods, but by the end of the decade the composition changed in favour of industrial goods. The share of industrial goods reached 79.3 per cent of the total exports, whereas only 18 per cent of total exports were agricultural goods. Furthermore, Turkey expanded its trade with the non-OECD countries, mainly the Middle East. Thus, the share of Middle Eastern and North African markets in total exports jumped from 17.8 per cent in 1980 to 41.9 per cent in 1982 , eventually stabilizing around 33.0 per cent by 1985. This phenomenal improvement in export performance was the result of both decisive changes in economies policies and external effects, such as the emergence of the Middle Eastern market with the eruption of the Iran-Iraq war in the early decade.

Table 8.1 documents important aspects of the relevant policy tools. As can be observed, real currency depreciation seems to be the primary instrument in the promotion of export targets and the achievement of balance in the current account. The exchange rate is devalued by 30 per cent between 1979 and the end of 1980. Starting from May 1981 , the exchange rate was adjusted daily and the parity was tied to a sliding crawling-peg. Consequently the Turkish lira depreciated by another 30 per cent in real terms between 1981 and 1985 .

In addition to adjustments in the real exchange rate, efforts at trade liberalization included incentives such as tax rebates, credit subsidies, an exchange retention scheme, and duty-free imports for the production 


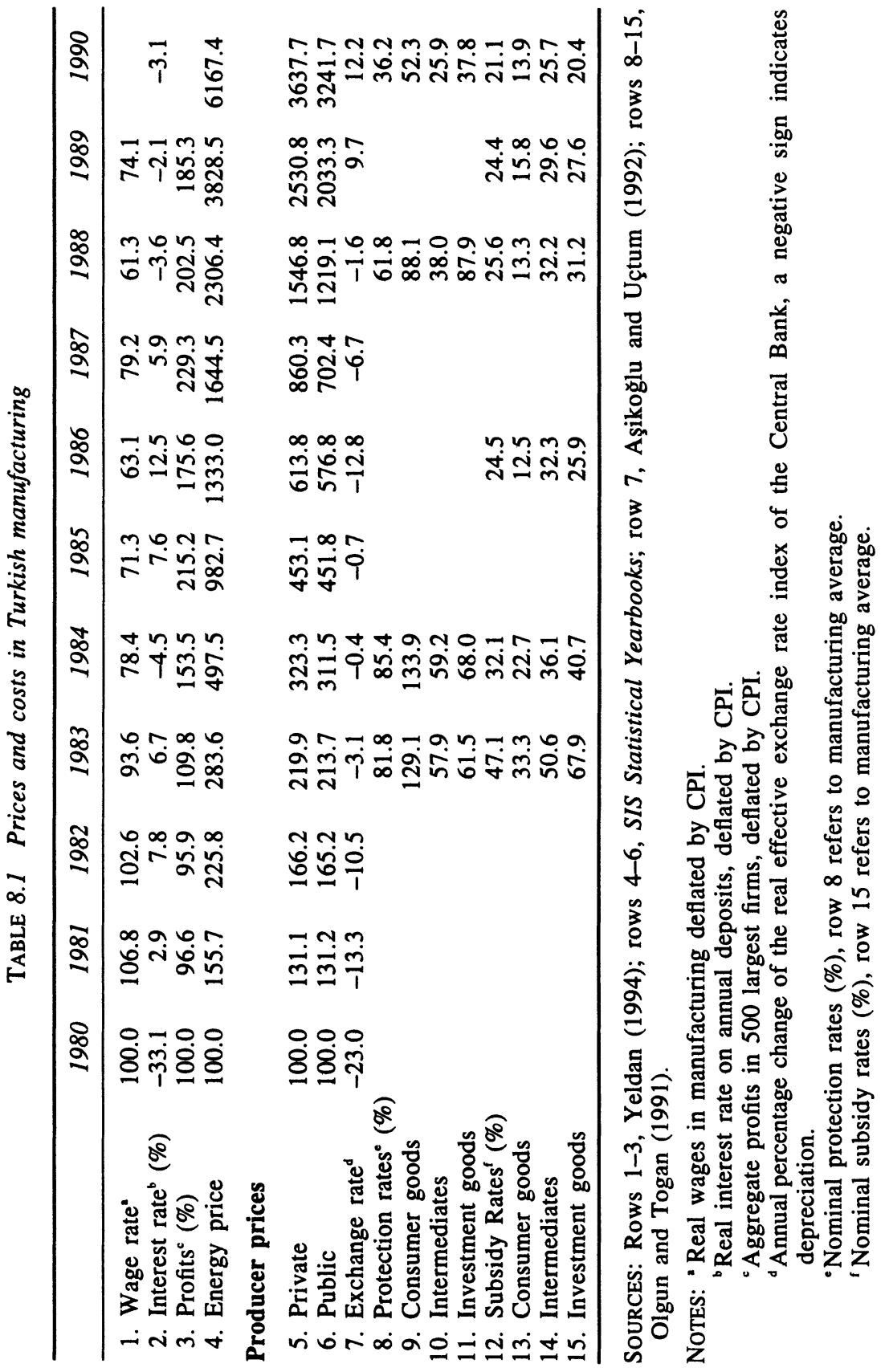


of exportables. Non-traditional exporting sectors such as metal products, machinery and transport equipment have had further preferential treatment. Import liberalization measures, such as reduction of quantitative restrictions, were introduced in 1980. Another critical reform in the trade regime was further liberalization of imports, announced in December 1983. The tariff rates were decreased, a substantial amount of quantitative restrictions were eliminated, and instead of the previous practice, which listed only the commodities which were free of all duties, a prohibitive list which was significantly less binding was put into practice. These changes in trade policies increased the role of market forces and decreased the anti-export bias in the trade regime.

As a consequence of a series of bold reforms towards financial liberalization, domestic financial markets gained depth and flexibility. Market rates of interest turned positive in real terms. This, however, resulted in a reduction in the share of entrepreneurial profits in the non-wage value added because of increased interest costs. Concurrently, a price reform was implemented, which aimed at correcting the existing distortions in the domestic price system which were especially prevalent in the state enterprise sector.

A closer look at the behaviour of these policy variables for the second half of the decade, however, shows a weakening of managerial activity of the bureaucracy. We witness what seems to be a reversal of macro-policies - a phenomenon for which Ersel (1991) coins the term 'reform fatigue'. In particular, if we examine the overall patterns of protection, we see that trade protection, even though curtailed to a large extent, continued, standing at an average rate of 36.2 per cent in 1990. A similar pattern is observed in the care of export promotion policy, with a secular downward movement in the subsidy element reaching an average of 21 per cent of manufacturing exports.

During this period, the inflation rate soared and the exchange rate began to appreciate in real terms. Real rates of interest turned negative. An important consequence of the loss of momentum in the implementation of price reforms is apparent: until 1985, the price indexes for the public and private manufacturing sector moved together. However, from 1986, the spread between the two widened in favour of the private sector. This observation suggests that the pricing policy in the state sector from 1986 onwards failed to exploit the market signals, while the private sector succeeded in doing so.

In sum, the Turkish export-led growth strategy failed to generate an indigenous momentum of its own, and receded into a phase of uncertainty 
in which 'political rationalities' finally came to grips with 'economic realities'. The limits of classic liberalization, based on statistical efficiency gains, seem to have been reached with cyclical growth patterns in the product and factor markets. We analyse the sectoral consequences of this episode in more detail in the next section.

\section{SECTORAL COMPOSITION OF TURKISH EXPORTS}

The success of Turkey's new outward-oriented growth policy is attributed to the spectacular increase in its exports and significant changes in the composition of Turkish exports during the 1980-90 period. Exportled development strategy with sizeable export subsidies and real exchange rate policies led to a much faster expansion in the industrial product exports. While the overall exports increased fourfold, the industrial product export increased tenfold during the decade (Table 8.1). With rapid increase in the share of industrial goods exports, the composition of the total exports changed drastically in favour of industrial goods. At the beginning of the period, 57.5 per cent of the total exports were agricultural goods and only 35.9 per cent were industrial goods. By the end of the period, the share of industrial goods had reached 79.4 per cent of the total exports whereas only 18 per cent of total exports were agricultural goods. ${ }^{2}$ Turkey moved from being mainly an agricultural goods exporter to an industrial goods exporter (see Table 8.2).

It is widely accepted that export expansion exerts a positive impact on economic growth and that the composition of exports is an important factor in the economic growth process. Ever since the effect of the enunciation of the Singer-Prebish thesis - that primary commodity exports suffer a long-term deterioration in terms of trade - the commodity composition of many of the developing countries exports has changed in favour of manufactured exports. Among all the developing countries which changed their development strategy and increased the share of manufactures in exports, there is no other country which has achieved as rapid a transformation of its export composition as Turkey during $1965-85 .^{3}$

Prior to 1980, Turkey followed an import-substitution development strategy which advocates industrialization with high protection of the domestic industry. The required protection was obtained through high tariffs and quantity restrictions on imports and with overvalued exchange rates. After 1980, the change in the development strategy towards a market-oriented export-led growth emphasized the importance 


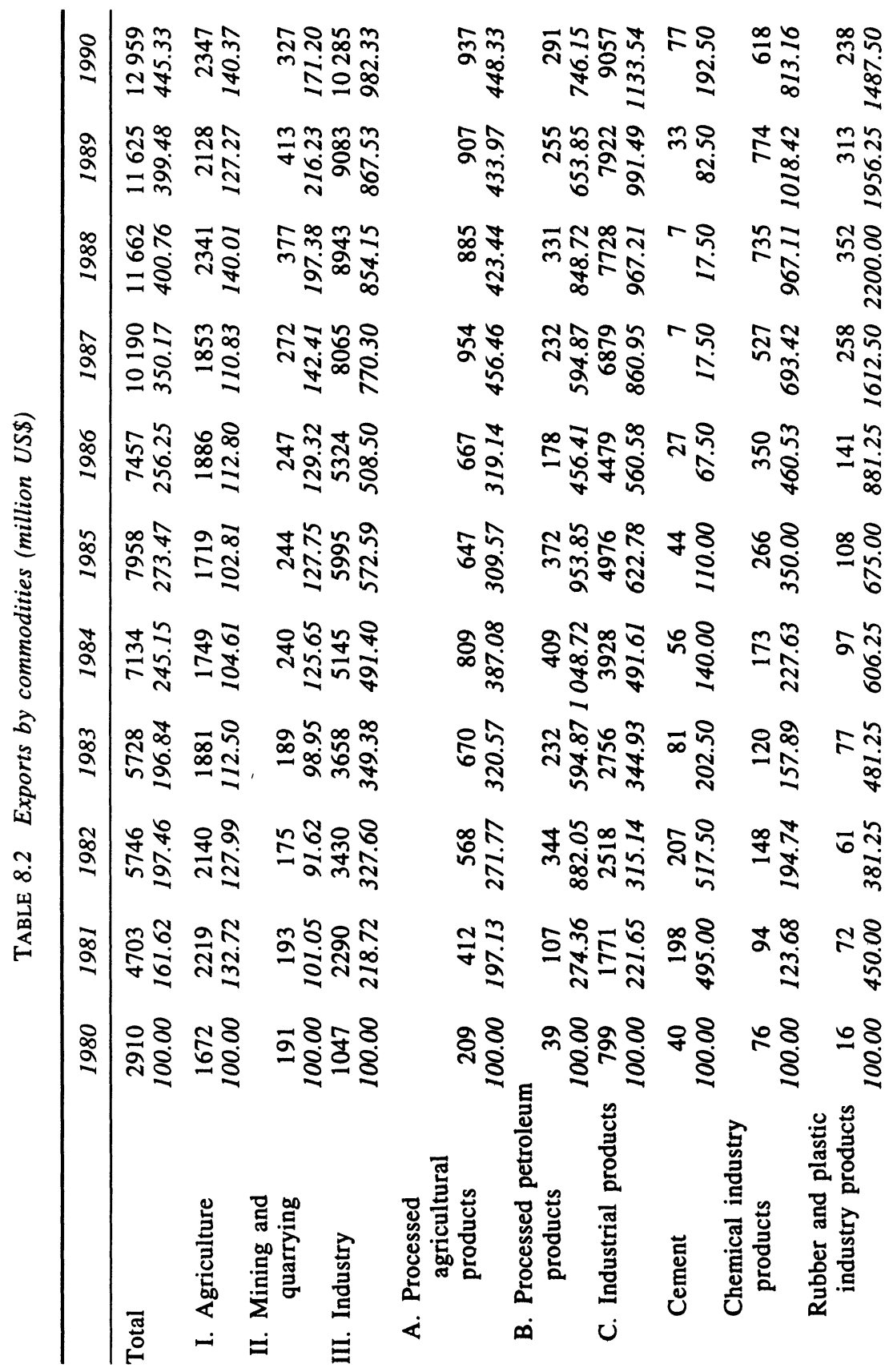




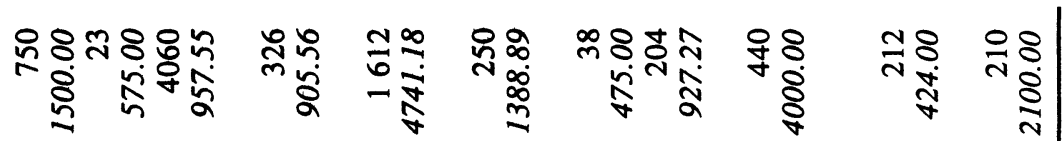

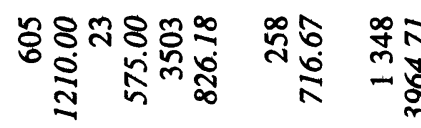
ท

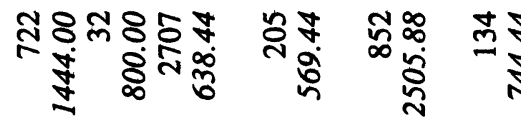

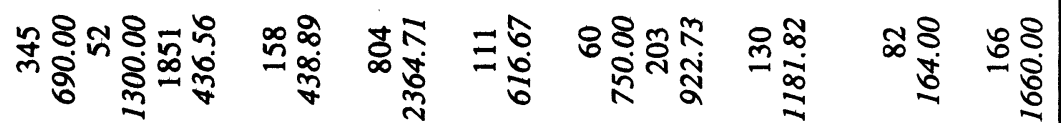

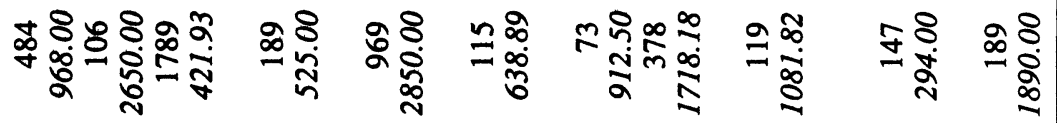

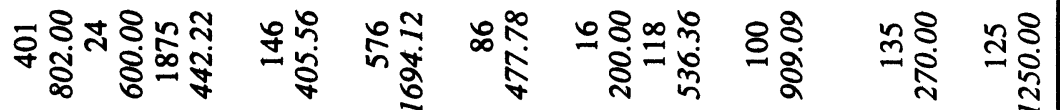

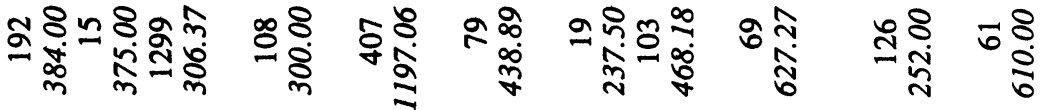

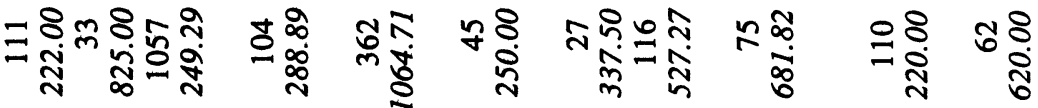

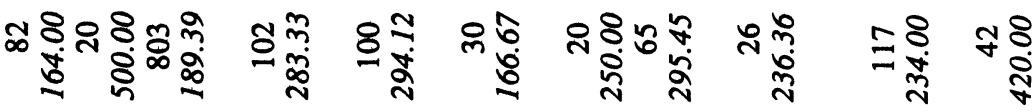

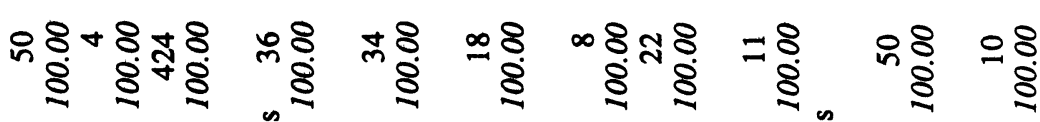






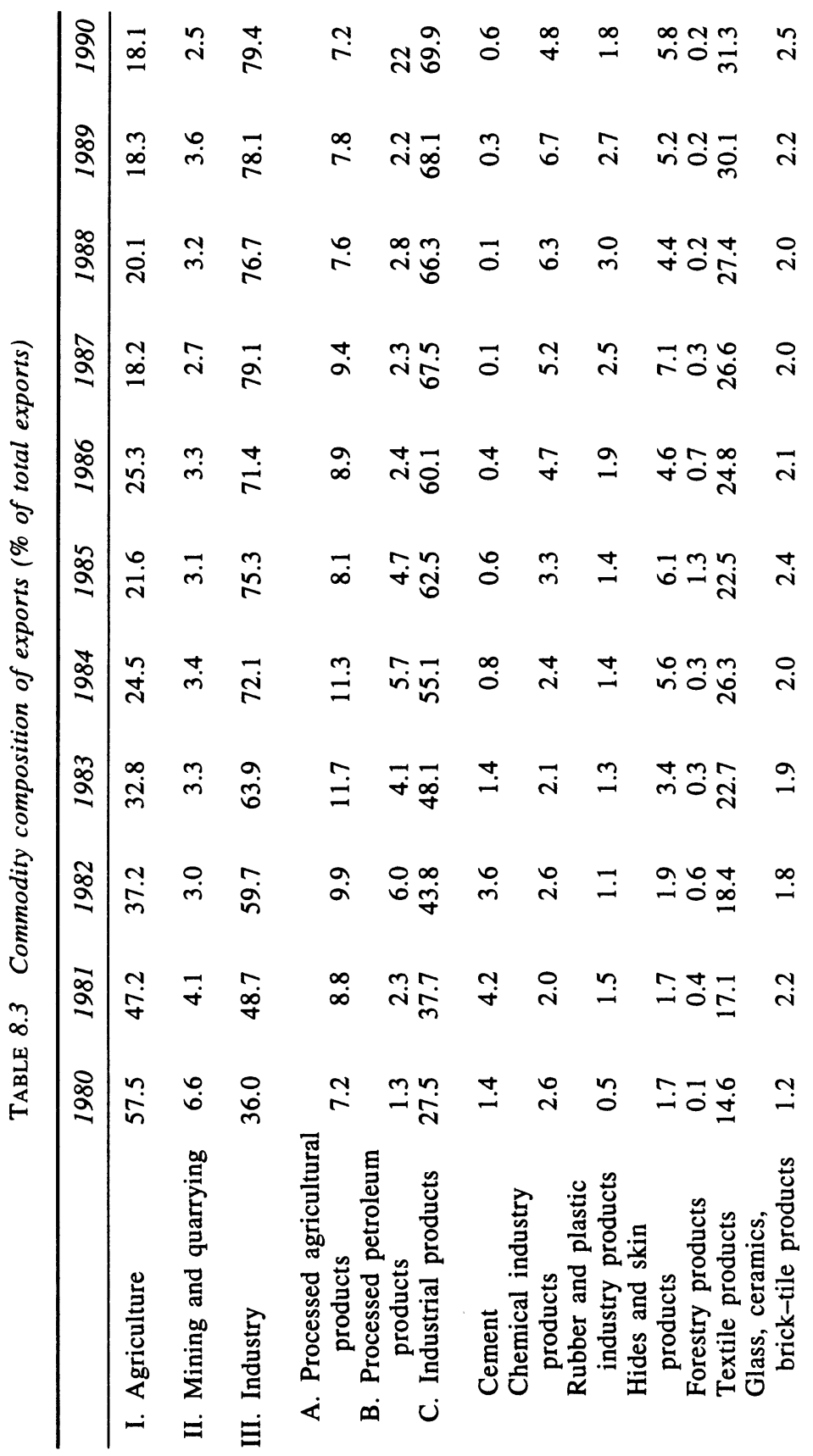




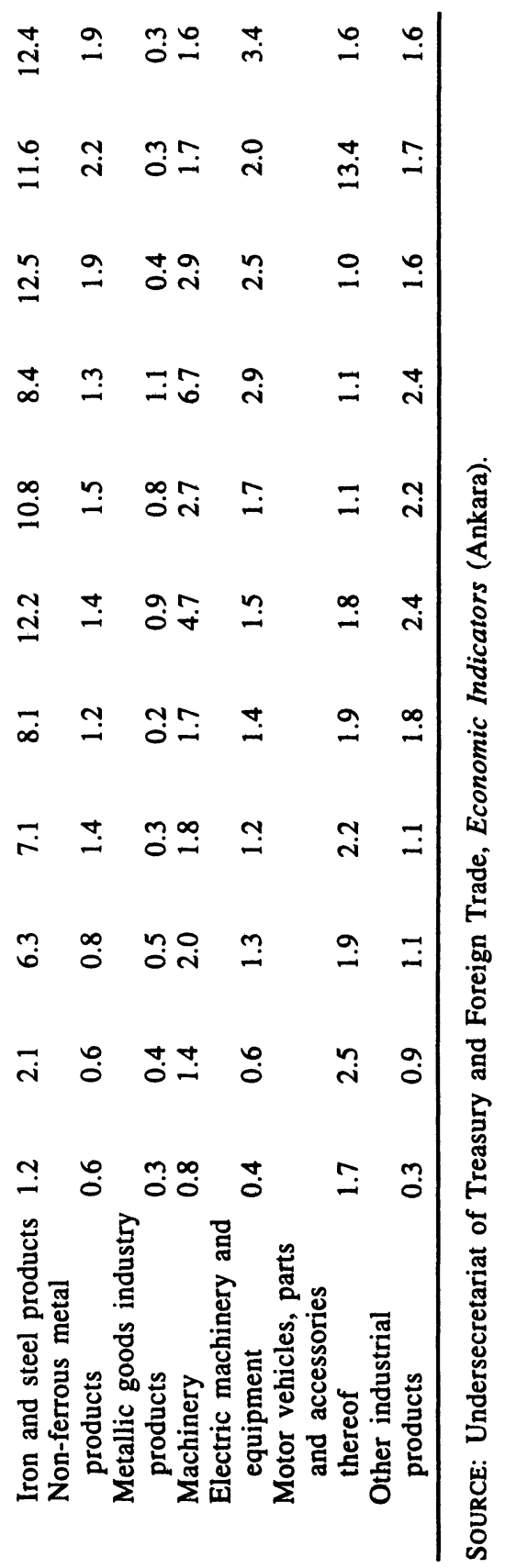


of exports, specifically manufactured exports. Accordingly, a series of export-promotion schemes was put into effect during the period. These schemes were sector specific and had differing impacts on the various sectors. The nominal rates of subsidy show that the manufacturing sector received preferential treatment with the highest nominal subsidy rates compared with the agriculture and mining and energy sectors. Within industry, intermediate and investment goods had the highest subsidy rates. The subsidies for consumer goods were low but, among these, durables and non-durables received relatively high subsidies (Togan, 1992).

There are wide differences in the growth rates of sectoral exports within manufacturing industry. Textiles, the traditional manufactured exports of Turkey, maintained their importance. In 1980, 14.5 per cent of the total exports were textile products, whereas in 199031.3 per cent of the total exports were from this industry. Textile products became the major export item of Turkey, with their value exceeding the value of total agricultural product exports by a factor of two. The fastest export growth was observed in two non-traditional export sectors: iron and steel products and electrical machinery and equipment (Table 8.3). By 1990, iron and steel products became the second most important manufactured exports with 12.4 per cent of total exports. In 1980 , only 1.2 per cent of exports were from this industry. Electrical machinery increased its share of total exports to 3.4 from 0.4 per cent during the same period.

Among the rest of the industrial products, traditional exports such as hides and skin products, and non-traditional export items like rubber and plastic industry products and non-ferrous metal products are the sectors whose exports grew faster than average industrial export growth. By 1990, after the change in the composition of exports, the hides and skin products industry (which comprise 5.8 per cent of total exports), chemical industry (4.8 per cent) electrical machinery and equipment ( 3.4 per cent), and glass, ceramic and brick-tile products (2.5. per cent) became the important industrial goods exports of Turkey (Table 8.3).

The main objective of the new development strategy was industrialization through export growth. Resources were reallocated from the agricultural sector to industry and the importance of industrial goods exports increased. However, the desired diversification of manufactured exports was not achieved during this period. Textile products, with 39.5 per cent of total manufactured exports, continued to be the major export item. Only a limited amount of diversification was obtained through growth in the share of iron and steel, hides and skins 




FIGURE 8.1 Composition of Turkey's manufacturing exports

and chemical industry product exports. The iron and steel products share was 15.7 per cent of total industrial exports in 1990. With these changes, the important manufactured exports became hides and skin products (7.3 per cent), chemical industry exports ( 6 per cent) and electrical machinery and equipment ( 4.3 per cent). These five manufacturing exports constitute 72.4 per cent of the total industrial product exports by 1990 , compared with a share of 56.5 per cent in 1980 (Figure 8.1).

The expansion in manufactured exports was concentrated in relatively labour intensive sectors such as textiles, clothing and leather. There are some new export sectors, such as iron and steel and chemicals which increased in importance both in value of absolute exports and their share in total manufactured exports that are more capital intensive in their production technology. But their relative importance in total exports is not high (see Table 8.4).

Next, we turn to the sectoral properties of manufacturing industry and changes in production conditions, in order to illustrate the interaction between necessary output growth and export supply growth. The commodity classification of industrial products in the foreign trade and manufacturing industry data do not tally, but by using the information 


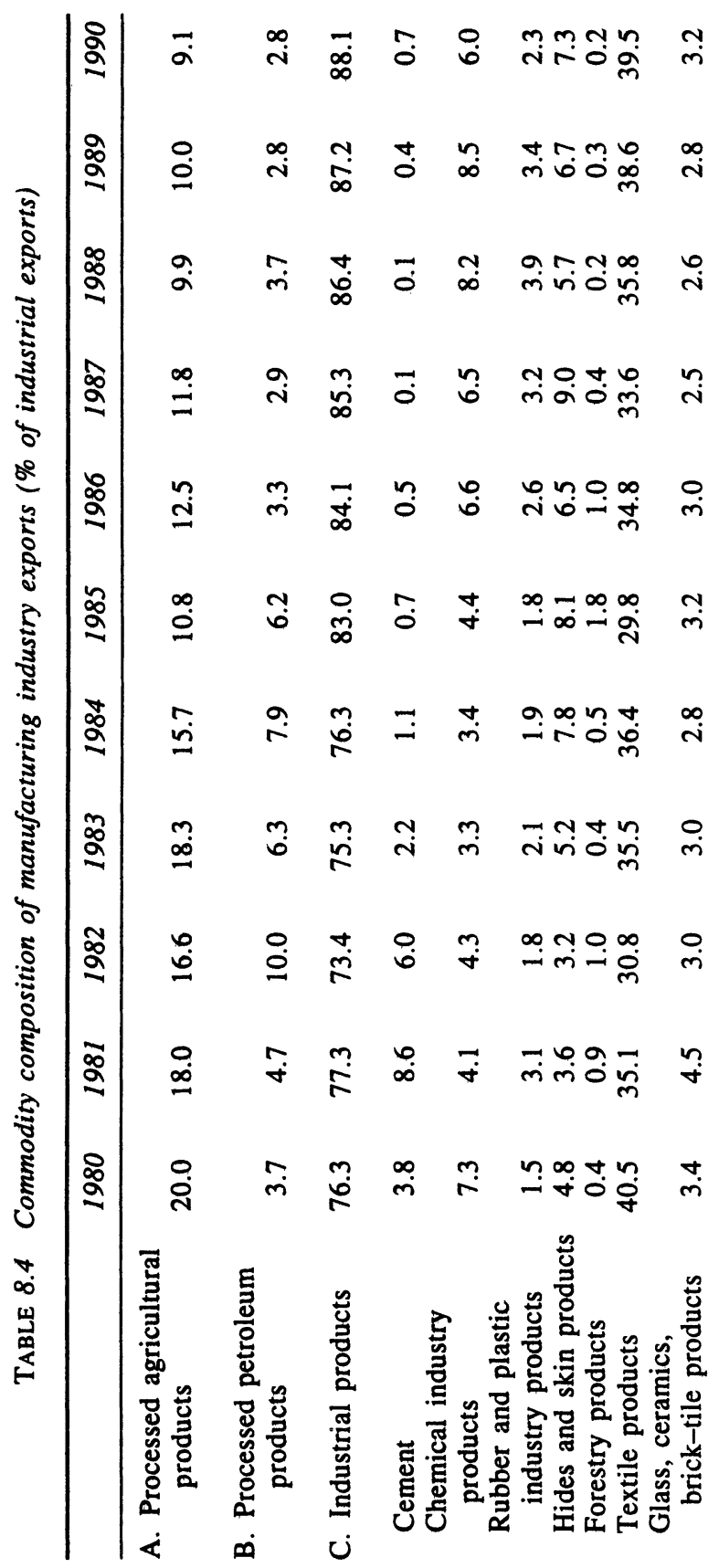




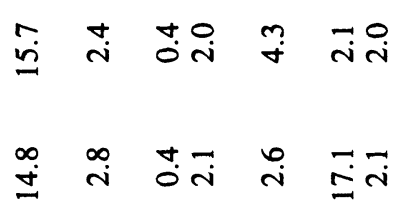

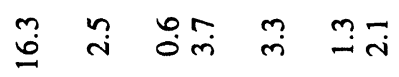

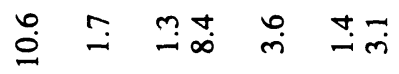

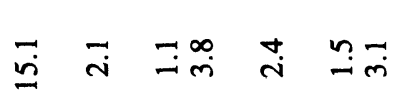

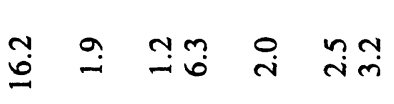

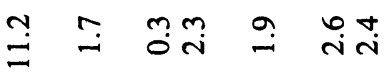

छ

号

ఫ高



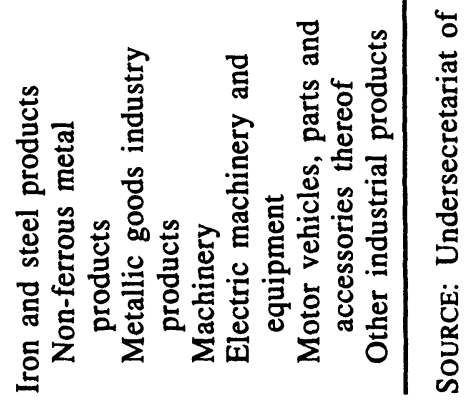


on the manufacturing industry it is possible to capture some of the crucial elements of the sectors whose products are major export items.

In an open economy, supply of exports can be increased either through increased production or reduced domestic absorption. Between 1980 and 1989, value added increased in all sectors (see Table 8.3 for the manufacturing sector data). Even though the rate of growth was slightly higher in the sectors whose outputs were also the main export items, such as basic metals and textiles, and slightly lower in sectors whose export growth was below average, such as forestry products, there is no definite relationship between the rate of export growth and output growth. It is clear that the growth of value added in all sectors lagged behind the growth of total exports from the sector. This provides some support for the contention that depressed domestic demand contributed to rapid export expansion.

Although at a slower pace than the expansion in exports, the increase in manufacturing output led to changes in the capital and labour use of sectors. The incremental capital output ratio in all sectors increased in the first half of the period and showed a decline towards the end of the decade. The largest increase in the incremental capital-output ratio was observed in textiles and basic metals, the two most important export items.

Although the incremental capital output ratio grew in all sectors, there were wide differences in the rate of capital accumulation between sectors. There are no clear relationships between the differential investment rate, export performance and the export subsidies given to the various sectors. All manufacturing industry, except for food processing and mining, was receiving above-average export subsidies during the period. Exports of iron and steel, non-ferrous metals, electrical machinery, chemicals, and rubber and plastic products received relatively high subsidies and showed rapid increase in exports. But among these sectors, the additions to capital stock was highest in iron and steel and electrical machinery. In the chemicals, rubber and plastic industries, with highly capital intensive production technology, the net additions to capital stock per unit of value added was the lowest among all sectors. On the other hand, forestry products, with high subsidy rates, showed a meagre expansion in exports, and output growth and investment per value added was the lowest among all the manufacturing sectors. Declining incremental capital-output ratios for the period proves that the export drive did not create enough impetus for expansion in capacity of the sectors and the initial expansion in output was achieved through the use of excess production capacity.

In order to examine the employment effect of export expansion in 
the manufacturing industry, one can evaluate the data for labour per unit of value added in all the sectors. If there are no changes in the production technology, this ratio will indicate the impact of output growth on employment in an industry. The most noticeable fact is that in all sectors, both labour-intensive sectors such as textiles, food processing and machinery and capital-intensive sectors such as chemicals and basic metals, labour per unit of value added declined throughout the period. Part of this decline can be attributed to labour productivity increase. Another explanation is that at the outset of export promotion policies, the sectors had both excess capacity and the labour employed was not fully utilized. The necessary expansion in output was achieved with increased utilization of the existing capital equipment and increased labour demand at a proportionately slower rate than the increase in output. Both the sectoral diversification created in the exports sectors towards capital intensive production, and the decline in labour per value added present a pessimistic picture in terms of the employment creation effects of export expansion.

Similar conclusions about the capacity expansion and employment effects follow from the performance of the capital-labor ratio in manufacturing. In most of the manufacturing sectors $K / L$ ratios declined during the period. This was observed in the case of both labour-intensive products, such as textiles and clothing, leather and food processing, and capital-intensive sectors, such as basic metals. In chemicals, rubber and plastics the $K / L$ ratios increased slightly during the first half of the decade and declined during the latter half. This also indicates that increased output was achieved with increased utilization of available excess capacity. The expansion of exports did not lead to a permanent increase in investment and capacity of production. These issues are elaborated upon in the next section.

\section{INTERFACE OF EXPORT EXPANSION, ACCUMULATION AND DISTRIBUTION}

We now turn to an analysis of the sectoral implications of export expansion to deduce the informal economic linkages between exports, employment, capital accumulation and distribution at the functional level. In so doing, we follow the consumer versus producer manufacturing dichotomy. We believe such a distinction is relevant, as it underscores the relative effectiveness of the non-traditional export expansion as opposed to that of the traditional sectors. 
More formally, we study two distinct routes of interface throughout the export-led growth episode; first is the exports-employmentexchange rate linkage. Second, we investigate the linkage between sectoral capital accumulation and the profit-wage frontier. We do not, however, analyse cause-effect relationships, since it is our contention that the movements of each indicator are intermixed with each other to such a degree that isolation of any one as the 'causal' link may be misleading.

Figure 8.2 depicts the first mechanism we are interested in. Here we plot export per worker ( $X / L$ on the left-hand scale), and depreciation versus wage costs (on the right-hand scale) in the consumer (Figure 8.2a) and the producer (Figure 8.2b) manufacturing industries from 1980 to 1989. The exports per worker indicator takes account of both sectoral export expansion and employment expansion. Thus, a steep rise in the $X / L$ ratio is a mixed blessing in that, while it shows successful export performance, it also signals meager employment creation in the sector. On the right-hand scale, we treat labour as our numerate entity, and we normalize the nominal exchange rate by the nominal wage rate. Here again, the observed indicator is the result of two effects: while exports are promoted by depreciation of the exchange rate, rising wage costs inhibit export performance. The latter effect occurs both because of increased production costs and increased domestic consumption demand which diverts producers away from export markets towards domestic markets.

Figures $8.2 a$ and $b$ show a direct relationship between exports per worker $(X / L)$ and the exchange rate over wage ratio $(E R / W)$. This is true for both the consumer and the producer manufacturing, yielding almost the same $X / L$ ratios over time. Per contra, the $E R / W$ ratio is observed to rise until 1985 and to taper off with a sudden fall in 1989. Here, the ratio follows a higher numerical value in the consumer manufacturing. This reveals that the wage renumerations were higher in the non-traditional (producer manufacturing) industries; or, to put it differently, traditional sectors, which are labour intensive in character, exploited wage reductions quite successfully. As Table 8.1 attests, average wage rates in manufacturing fell by as much as 40 per cent in real terms between 1980 and 1988. Yeldan (1993) confirms that this trend was more pronounced in the private sector since, in most cases, public enterprises continued to employ labour at politically regulated wage rates. While it is a widely recognized fact that the quality of such data on factor incomes is limited and suffers from severe shortcomings. Many independent researchers confirm a severe decline in the share of wage income, 


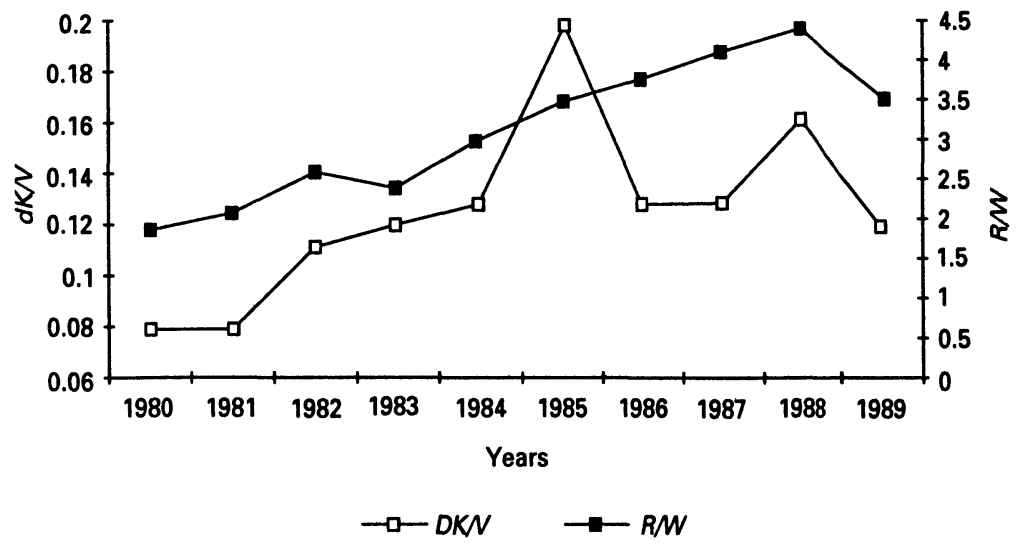

$D K N$ : ratio of gross additions to capital stock to aggregate value added $R W$ : ratio of aggregate profits to aggregate wages

FIGURE $8.2 a$ Capital accumulation and the profit-wage frontier in consumer manufacturing

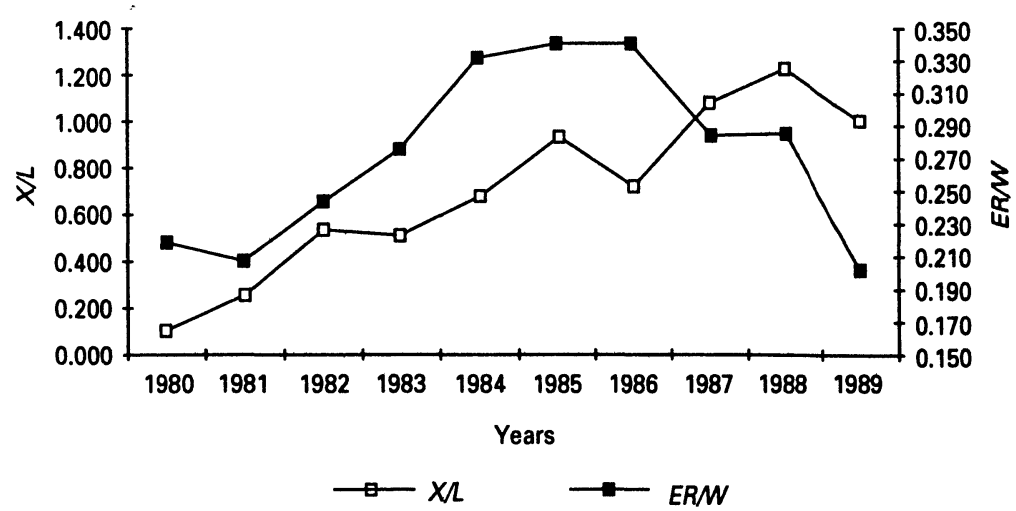

$X / \quad$ : real exports (in 1980 million $T L$ ) per worker employed

$E R W$ : exchange rate (TL/\$) - wage rate (in current thousands $T L$ ) ratio

FIGURE $8.2 b$ Exports per worker and depreciation versus wage costs in producer manufacturing 
and of the size of the non-labour component of manufacturing value added in the 1980s. Ozmucur (1991) for instance, argues that the share of non-wage income in non-agricultural value added increased from 65 per cent in 1980 to 72 per cent in 1991.

It is to be noted that price inflation was one of the major components of this mechanism enabling the wage squeeze to be captured both as surplus profits for the producers and as inflation tax revenues for the state. Implemented under a regime of continued currency depreciation supplemented by direct export incentives, inflation policy did not lead to any loss of competitiveness of Turkish exportables. This mechanism, however, lost steam by 1988 as the possibilities of prolonged depreciation and wage suppression finally came up against 'political reality' (Onis, 1991).

The interaction of the exchange-rate administration with the wage cost realization documents a three period categorization of the exportled path in the 1980s: the first sub-period covers 1980 through mid1983, when the sector 'recovered' and responded to the market signals which were transmitted through depreciation of the currency and the price reforms. Here, $X / L$ starts to gradually pick up, while the downward movement in $E R / W$ occurs at a modest scale. However, in the second sub-period, from 1983 to the end of 1986, both series disclose an abrupt acceleration. We believe it is in this sub-period that the classic mechanism of surplus extraction for export promotion could have been exploited in Turkish manufacturing: wage costs were held down in real terms; liberalization provided new sources of funding in financial markets; and exchange rate administration had 'matured' in the sense that the process responded to incentives without the need for sudden devaluation on a massive scale.

The strategy began to disintegrate beginning in 1987, and the export performance of the sector faltered. The domestic economy was faced with the uncertainties which we have earlier referred to as the 'reform fatigue' phenomenon. In other words, policies contributing to export-led growth paths could not be sustained.

We now turn to an investigation of the pattern of capital accumulation in the face of developments in the profit-wage frontier over the decade. For this purpose we utilize information exhibited in Figures $8.3 \mathrm{a}$ and $8.3 \mathrm{~b}$. On the left-hand scale of Figures $8.3 a$ and $8.3 b$, we plot the ratio of 'gross additions to capital stock' to sectoral value added $(d K / V)$. This data covers expenditures made on new or used fixed assets purchased from the domestic market, fixed assets imported, and fixed assets produced by the establishment's own staff. Major repairs 


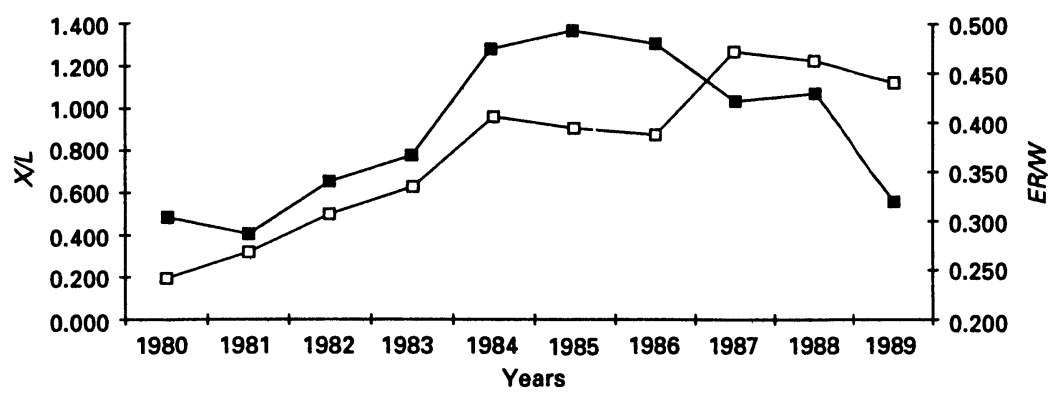

$X / L \quad$ : real exports in (in 1980 million TL) per worker employed

ERW : exchange rate (TL/\$) - wage rate (in current thousands $T L$ ) ratio

FIGURE 8.3a Exports per worker and depreciation versus wage costs in consumer manufacturing

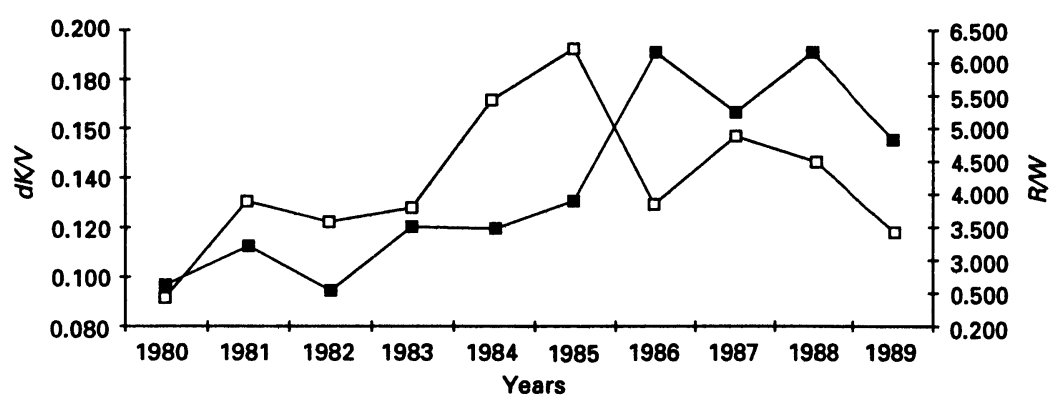

DKN : ratio of gross additions to capital stock to aggregate value added $R W$ : ratio of aggregate profits to aggregate wages

FIGURE 8.3b Capital accumulation and the profit-wage frontier in producer manufacturing

and expenditures made on plant studies and plans as well as on land improvements are included in this category.

We compare this ratio with the historical path of profits-wages ratio $(R / W)$ which appears on the right-hand scale. Thus we adopt an accelerationist approach to capital accumulation, in response to signals of profitability and labour costs. Data reveal a secular upward movement in the $d K / V$ ratio in both sectors, reaching a peak of approximately 0.2 in 1985 . It is interesting to note that from 1985 the consumer goods and producer goods industries exhibit divergent factor-industries. 
Re-interpreting $d K / V$ values as incremental capital-output ratios, we observe that in the first half of the decade, consumer manufacturing displays a lower score, as is to be expected given its labour-intensive character. After 1985, however, $d K / V$ of consumer manufacturing exceeds that of producer manufacturing, with the single exception for the year 1987. This suggests a sluggish growth of capital investments in the producer manufacturing industries, with consequences for productivity growth in the longer run. Clearly, much remains to be understood with regard to the meagre performance of capital accumulation over the decade. As Rittenberg (1991) reports, private fixed investments grew at about half the rate of growth of the pre-crisis period, returning to its 1979 level only after 1986. Thus, aggregate manufacturing investments increased by only 15 per cent in real terms at the end of the decade as compared to their 1980 values.

However, the industrial enterprises appear to have capitalized on the on-going export expansion through sharp shifts in the profit-wage frontier, which can be regarded as a necessary condition for the adoption of the new strategy by the capital owners. The growth of the $R / W$ ratio was especially pronounced in producer manufacturing.

In sum, the export-led growth strategy accomplished an important transformation in the composition of Turkey's exports and promoted resource reallocation from the agricultural sector to industrial sectors. However, the necessary level of diversification of strategy did not lead to the hoped-for industrial product exports. The traditional manufactured exports items continued to account for the bulk of exports. The distinguishing characteristic of the Turkish export performance during the period was that it rested on the extraction of resources for exports by suppressing domestic demand through wage reduction and currency devaluation. This surplus was exported to foreign markets with the provision of generous subsidies and led to increasing profits. This process, however, had limited resource-pull effect on the rest of the economy, and could not lead to rapid labour employment. Coupled with an overall decline in the share of physical investments in traded goods, such export expansion based on wage reductions and price incentives hit its political limits in the late 1980s and began to falter. It is unlikely that in the near future this rapid increase in exports will continue and the newly emerging export sectors will increase their overall significance in the economy.

The new 'strategy' of export-led expansion, however, biased incentives towards export-oriented manufacturing capital, but this lasted for only a relatively short time span, which was not long enough to lift the economy'on to a sustainable growth path. 


\section{NOTES}

1. Note that the quoted figure is an amalgam of various 'officially' set rates of tariffs, tax-like surcharges and various levies. Thus, the 'actual' rate of protection which includes concessions and/or evasions, yields a smaller figure. For elaboration of this point, see Celâsun (1992).

2. Industrial good exports include 7.2 per cent of processed agricultural products, 1.3 per cent of processed petroleum products and 27.5 per cent of industrial product exports. The increase in the industry exports share was due to the increase in the industrial products. The share of the processed agricultural goods exports and petroleum products remained the same through the period, but the share of the industrial products increased to 69.9 per cent of the total exports.

3. The only country which came close to changing its export composition towards manufactured good exports as rapidly is Taiwan, which increased the share of the manufactured export from 41.3 to 80.2 per cent between 1965 and 1976 (Sarkar and Singer, 1991).

\section{REFERENCES}

Asikoglu, Y. and Uctum, M. (1992), 'Exchange Rates in Turkey', World Development, vol. 20, pp. 1501-14.

Boratav, K. (1992), 1980'li Yillarda Turkiye'de Sosyal Siniflar ve Bolusum (Istanbul: Gercek Yay).

Celâsun, M. (1989), 'Income Distribution and Employment Aspect of Turkey's Post-1980 Adjustment', METU Studies in Development. vol. 16, nos 3-4, pp. 1-32.

Celâsun, M. (1992), 'Trade and Industrialization in Turkey: Initial Conditions, Policy and Performance in the 1980s', paper presented at the BilkentLancaster Joint Conference on the 'Turkish Economy since Liberalization', Ankara, October 1992 (mimeo).

Celâsun, M. and Rodrik D. (1989), 'Debt, Adjustment and Growth: Turkey', Book IV in J. Sachs and M. Collins (eds), Developing Country Debt and Economic Performance: Country Studies (Chicago, IL: The University of Chicago Press).

Ersel, H. (1991), 'Structural Adjustment: Turkey, 1980-1990', paper presented at the IMF-Pakistan Administrative Staff College Joint Seminar, Lahore, 26-28 October 1991 (mimeo).

Olgun, H. and Togan, S. (1991) 'Trade Liberalization and Structure of Protection in Turkey in the 1980s: A Quantitative Approach', Weltwirtschaftlishes Aerchiv, vol. $127(1)$, pp. 152-70.

Onis, Z. (1991), 'Political Economy of Turkey in the 1980s: Anatomy of Unorthodox Liberalism', in M. Heper (ed.), Strong State and Economic Interest Groups: The Post-1980 Turkish Experience (Berlin: de Gragter) Ch. 2.

Onis, Z. and Riedel, J. (1993), Economic Crises and Long-Term Growth in Turkey (Washington, DC: World Bank). 
Ozmucur, S. (1991), 'Price and Income Distribution', Bogazici Universitesi Research Papers, No. 155/EC 91-17.

Rittenberg, L. (1991), 'Investment Spending and Interest Rate Policy: The Case of Financial Liberalization in Turkey', Journal of Development Studies, vol. 27, pp. 151-67.

Sarkar, P. and Singer, J. W. (1991), 'Manufactured Exports of Developing Countries and Their Terms of Trade Since 1965', World Development, vol. 19 , no. 4 , pp. $333-40$.

Senses, F. and Yamada, T. (1990), Stabilization and Structural Adjustment Program in Turkey (Tokyo: Institute of Developing Economics Research Programme Series, no. 85).

State Institute of Statistics (SIS), Statistical Yearbook of Turkey (various years), Ankara.

Togan, S. (1992), Foreign Trade Regime and Liberalization of Foreign Trade in Turkey during 1980s (Ankara: Turkish Eximbank).

Yeldan, E. (1994), 'The Economic Structure of Power under Turkish Structural Adjustment: Prices, Growth and Accumulation', in F. Senses (ed.), Recent Industrialization Experience of Turkey in a Global Context (London: Greenwood Press) Ch. 6, pp. 75-80. 